\title{
RELATIONS BETWEEN VITAMIN D STATUS, MUSCLE TONE AND BODY COMPOSITION IN SOLDIERS: ASSOCIATION WITH LONG-TERM MISSION
}

\author{
Tatjana Kums ${ }^{1}$, Gudrun Veldre ${ }^{2}$, Erik Salum ${ }^{2}$, JaAn Eha ${ }^{2}$ \\ ${ }^{1}$ Institute of Exercise Biology and Physiotherapy, University of Tartu, Estonia \\ ${ }^{2}$ Department of Cardiology, University of Tartu, Estonia
}

\begin{abstract}
Vitamin D level is known to play an important role in the regulation of different human functions, including the functions of the cardio-vascular and musculoskeletal systems. The aim of the study was to find relations between vitamin D level, skeletal muscles tone and body composition in conditions of prolonged physical load.

Sixty-five well-trained male soldiers from the Estonian ESTCOY-8 infantry company were examined before and after a six-month military mission to assess the soldiers' vitamin $\mathrm{D}$ level, skeletal muscles tone and body composition.

The results of the study showed that, during the long-term military mission, muscle tone of lower extremities decreased in conditions where vitamin D status was significantly increased (from average 40 to $104 \mathrm{nmol} / \mathrm{L} ; \mathrm{p}<0.001$ ). We also found that the upper and middle part $m$. trapezius tone increased significantly during long-term strenuous military mission.

Our study showed that the long-time military mission influenced the skeletal muscles functional state. Decrease in muscle tone of lower extremities was related to increase in serum vitamin $25(\mathrm{OH}) \mathrm{D}$ level (in average by $64 \mathrm{nmol} / \mathrm{L}$ ). At the same time muscle tone of $m$. trapezius increased in our group of subjects, and this increase was linked to WHR.
\end{abstract}

Keywords: muscle tone, serum vitamin $25(\mathrm{OH}) \mathrm{D}$, waist-hip ratio (WHR) 


\section{INTRODUCTION}

Roles for vitamin $\mathrm{D}$ have been established in the function of the cardiovascular, immune and musculoskeletal systems $[13,7]$. Impairment of different body systems (including the immune and cardiovascular systems) during prolonged physical load is well known $[6,19]$. Different studies $[5,4,14]$ have suggested that vitamin $\mathrm{D}$ maintains physical performance, and poor vitamin $\mathrm{D}$ status affects muscle strength. Vitamin D deficiency has been proposed to cause muscular impairment before adverse effects occur in bone. So, Glerup et al [5] have shown that proximal muscle weakness is a salient feature of clinical vitamin $\mathrm{D}$ deficiency. At the same time, it is well known that vitamin $\mathrm{D}$ is an essential nutrient obtained from the diet and exposure to sunlight [11]. Muscle tone, also termed tonus by definition of Gale Encyclopaedia of Medicine, is the normal state of balanced tension in the body muscles. A muscle with high tone is stiffer than usual and is more difficult to stretch [12]. We could not find any studies about the relations between vitamin $\mathrm{D}$ status and muscle tone.

Therefore, we were interested in examining well-trained soldiers before and after a strenuous military mission to assess the effect of long-term physical load on soldiers' skeletal muscles tone in relation to their body composition (including waist-hip ratio - WHR) and vitamin D level. These Estonian soldiers were shown to achieve normal levels of $25(\mathrm{OH}) \mathrm{D}$ after the mission, although they had vitamin $\mathrm{D}$ insufficiency $(25(\mathrm{OH}) \mathrm{D}<50 \mathrm{nmol} / \mathrm{L})$ before deployment in Afghanistan [17].

\section{MATERIAL AND METHODS}

Thirty-six well-trained male soldiers (age $=26 \pm 4$ before the mission) from the Estonian ESTCOY-8 infantry company were examined before and after a sixmonth military mission in Afghanistan. This study was a small part of a larger examination of the Estonian ESTCOY-8 infantry company soldiers conducted by the Department of Cardiology, University of Tartu, supervised by Prof. Jaan Eha, that has been partly reported by Salum et al. in 2011 [17] and partly by Veldre et al in 2011 [21]. The study was approved by the Institutional Ethics Committee, and informed consent was given by each participant. Body height, body weight, waist circumference and hip circumference were measured according to Martin and Saller (1956) [10] in the ordinary way. BMI was calculated as the body weight $(\mathrm{kg})$ divided by the square of the standing 
body height $(\mathrm{m})$. The functional state of skeletal muscle tone of soldier's $m$. erector spinae (ES) tone $(\mathrm{Hz})(\mathrm{ES})$, upper, middle, lower $m$. trapezius muscle tone $(\mathrm{TR}(\mathrm{A}, \mathrm{B}, \mathrm{C}), m$. biceps femoris $(\mathrm{BF})$ and $m$. rectus abdominis $(\mathrm{RA})$ before and after mission was assessed by using myotonometric measurements with the Myoton-2 myometer, created at the University of Tartu, Estonia [20], and improved in different studies $[1,22]$.

Body composition (body fat percentage, visceral fat level and skeletal mucle percentage) was assessed by OMRON Body Composition Monitor BF500.

Enrolled subjects' serum samples 25-hydroxyvitamin D (25(OH)D) assay was analysed in the centralized laboratory of Tartu University Hospital.

Statistical analysis was performed using the SPSS software package version 17.0 (SPSS, Inc., Chicago, Illinois). Paired Samples Test was used to compare a person's variables before and after the military mission. The level of $\mathrm{p}<0.05$ was selected to indicate statistical significance.

\section{RESULTS}

The mean variables of the subjects before and after the six-month military mission are shown in Table 1.

During the mission, vitamin D level and tone of the body (upper and middle $m$. trapezius tone) and tone of the lower extremities (tone of $m$. biceps femoris, $m$. rectus femoris and $m$. tibialis anterior) changed statistically significantly. Vitamin D level increased significantly $(\mathrm{p}<0.0001)$ in the studied soldiers during mission time. There was a statistically significant $(\mathrm{p}<0.01)$ decrease in the tone of $m$. rectus femoris and $m$. tibialis anterior (respectively from $12.3 \pm 1.38$ to $10.1+0.80 \mathrm{~Hz}$ and from $17.4 \pm 1.49$ to $14.9 \pm 1.86 \mathrm{~Hz})$ and a significant $(\mathrm{p}<0.05)$ decrease in the tone of $m$. biceps femoris $(13.2 \pm 1.42$ vs.10.9 $\pm 1.69 \mathrm{~Hz})$. Differently from the tone of the lower extremities, the tone of the upper and middle part of the $m$. trapezius $(\mathrm{p}<0.05-0.01)$ increased significantly during the mission (respectively from $12.0 \pm 1.80$ to $13.1 \pm 1.25 \mathrm{~Hz}$ and from $9.7 \pm 0.79$ to $10.5 \pm 1.21 \mathrm{~Hz}$ for the upper and middle part of $m$. trapezius).

Although there was a tendency towards unfavourable changes in body composition (towards an increase in fat content and a decrease in skeletal muscles percentage) during the mission, these changes were not statistically significant during the six-month period. Changes of the other variables studied (body height and weight) were insignificant (Table 1). 
Table 1. Characteristics of the studied soldiers $(n=65)$ before and after the six-month military mission

\begin{tabular}{|c|c|c|c|c|c|}
\hline \multirow[b]{2}{*}{ Variable } & \multicolumn{2}{|c|}{ Mean } & \multicolumn{2}{|c|}{ SD } & \multirow{2}{*}{$\begin{array}{l}\text { Significance of the } \\
\text { change by Paired } \\
\text { Samples Test }\end{array}$} \\
\hline & $\begin{array}{l}\text { Before } \\
\text { mission }\end{array}$ & $\begin{array}{c}\text { After } \\
\text { mission }\end{array}$ & $\begin{array}{c}\text { Before } \\
\text { mission }\end{array}$ & $\begin{array}{c}\text { After } \\
\text { mission }\end{array}$ & \\
\hline Body height $(\mathrm{cm})$ & 182.3 & 182.2 & 7.10 & 7.05 & NS \\
\hline Body weight (kg) & 79.0 & 78.9 & 10.61 & 10.29 & NS \\
\hline BMI (kg/m²). & 23.8 & 23.9 & 2.71 & 2.41 & NS \\
\hline 25(OH)level (nmol/L) & 39.7 & 104.3 & 14.36 & 24.23 & $p<0.0001(p=0.0000)$ \\
\hline$\%$ of skeletal mucles & 41.32 & 40.7 & 2.89 & 2.25 & NS \\
\hline Visceleral fat level & 5.6 & 6.1 & 2.81 & 2.50 & NS \\
\hline$\%$ of fat & 17.0 & 17.7 & 4.45 & 3.86 & NS \\
\hline WHRatio & 0.8 & 0.8 & 0.06 & 0.06 & NS \\
\hline $\begin{array}{l}\text { M. trapezius upper [TR }(\mathrm{A})] \\
\text { tone }(\mathrm{Hz})\end{array}$ & 12.0 & 13.1 & 1.80 & 1.25 & $p<0.05(p=0.045)$ \\
\hline $\begin{array}{l}\text { M. trapezius middle }[\mathrm{TR}(\mathrm{B})] \\
\text { tone }(\mathrm{Hz})\end{array}$ & 9.7 & 10.5 & 0.79 & 1.21 & $p<0.01(p=0.003)$ \\
\hline $\begin{array}{l}\text { M. trapezius lower }[\mathrm{TR}(\mathrm{C})] \\
\text { tone }(\mathrm{Hz})\end{array}$ & 10.3 & 9.66 & 1.78 & 1.15 & NS \\
\hline $\begin{array}{l}\text { M. erector spinae (ES) tone } \\
(\mathrm{Hz})\end{array}$ & 9.8 & 9.1 & 1.66 & 1.30 & NS \\
\hline $\begin{array}{l}\text { M. rectus abdominis (RA) } \\
\text { tone }(\mathrm{Hz})\end{array}$ & 9.8 & 9.5 & 1.48 & 1.53 & NS \\
\hline $\begin{array}{l}\text { M. biceps femoris (BF) tone } \\
(\mathrm{Hz})\end{array}$ & 13.2 & 10.9 & 1.42 & 1.69 & $p<0.05(p=0.032)$ \\
\hline $\begin{array}{l}\text { M. rectus femoris (RF) tone } \\
(\mathrm{Hz})\end{array}$ & 12.3 & 10.1 & 1.38 & 0.80 & $p<0.01(p=0.002)$ \\
\hline $\begin{array}{l}\text { M. gastrocnemius (GM) } \\
\text { tone }(\mathrm{Hz})\end{array}$ & 13.7 & 13.1 & 1.35 & 1.63 & NS \\
\hline $\begin{array}{l}\text { M. tibialis anterior }(\mathrm{TA}) \text { tone } \\
(\mathrm{Hz})\end{array}$ & 17.4 & 14.9 & 1.49 & 1.86 & $p<0.01(p=0.0013)$ \\
\hline
\end{tabular}

Pearson's correlation analysis showed that the upper and middle $m$. trapezius tone was in correlation with WHRatio (respectively $\mathrm{r}=0.66(\mathrm{p}=0.0001)$ and $\mathrm{r}=0.49(\mathrm{p}=0.012))$. The tone of the lower extremities was in inverse correlation with the change of vitamin $\mathrm{D}$ status $(\mathrm{r}=-0.39(\mathrm{p}=0.008)$ in $m$. rectus femoris and $\mathrm{r}=-0.38(\mathrm{p}=0.011)$ in $m$. tibialis anterior $)$. There were also statistically significant medium correlation coefficients between vitamin $\mathrm{D}(25-\mathrm{OH})$ and body composition variables (negative correlations with skeletal muscle percentage respectively $r=-0.45(p=0.006)$ before and $r=-0.46(p=0.004)$ after the mission, and positive correlations with body fat percentage $r=0.45(p=0.006)$ and with visceral fat percentage $r=0.45(p=0.006)$ before and $r=0.39(p=0.020)$ the after mission). 


\section{DISCUSSION}

It is well documented that vitamin $\mathrm{D}$ deficiency (25-hydroxyvitamin $\mathrm{D}$ level of less than $50 \mathrm{nmol} / \mathrm{L}$ ) is related to hypotonia, prolonged time of peak muscle contraction and delayed time of muscle relaxation [15]. This may indicate that vitamin $\mathrm{D}$ status could be connected with muscle tone. It is also known that vitamin $\mathrm{D}$ intoxication (25-hydroxyvitamin $\mathrm{D}$ to more than $150 \mathrm{ng} / \mathrm{L}$ ), although it is rare, is associated with hypercalcemia and hyperphosphatemia [9].

Although vitamin D insufficiency is ordinarily characteristic of Estonians, due to latitude differences and abundant exposure to UVB radiation, the vitamin D level increased significantly in soldiers during the mission. Vitamin D status of soldiers increased significantly in mission time (from average 40 to $104 \mathrm{nmol} / \mathrm{L})$.

Current reference level for sufficient $25(\mathrm{OH}) \mathrm{D}$ is $50 \mathrm{nmol} / \mathrm{L}[8,9]$. We were interested in how the change of $25(\mathrm{OH}) \mathrm{D}$ (mean increase of $25(\mathrm{OH}) \mathrm{D}$ $64 \mathrm{nmol} / \mathrm{L}$ ) influenced the functional state (tone) of the subjects' muscles.

Firstly, contrary to our expectations, our results showed that the long-term military mission affected the muscle tone of the lower extremities even in conditions where vitamin D status significantly improved. Different studies have shown that vitamin $\mathrm{D}$ may have an impact on muscle fibre composition and function.

A study of Sato et al. [18] found that treatment of elderly stroke survivors with 1000 IU of vitamin D2 significantly increased mean type II muscle fibre diameter and percentage of type II fiber over a 2 year period. There was also a correlation between serum 25(OH)D level and type II muscle fibre diameter both at baseline and after two years of follow-up [18].

Experiments in skeletal muscle have shown that biologically most active form of vitamin $\mathrm{D}\left(1.25(\mathrm{OH})_{2} \mathrm{D}\right)$ regulates muscle calcium uptake by modulating the activity of calcium pumps in sarcoplasmic reticulum and sarcolemma [2].

Modifications in intracellular calcium levels control contraction and relaxation of muscle, thus impacting muscle function $[2,3]$.

Thus, there are indirect suggestions [2] that too high increase of vitamin D level could affect muscle functions. Therefore, we can speculate that the rise of vitamin $25(\mathrm{OH}) \mathrm{D}$ level in average $64 \mathrm{nmol} / \mathrm{L}$ could be negatively related with the functional state of the muscles of lower extremities of the subjects.

Secondly, upper and middle part $m$. trapezius tone, which was in significant correlation with WHRatio, increased significantly during the strenuous longterm military mission. WHR is the ratio of the circumference of the waist to 
circumference of the hips used for measuring of abdominal obesity [16]. In our study, we found significant positive correlations of WHR with visceral fat percentage and body fat percentage.

How to explain the increase of the upper and middle part of m.trapezius tone but not of the lower part of m.trapezius in conditions of high physical load? It is evident that with the increase of WHR (associated with the increase of the anterior part of the body) we can expect higher tone of just the upper and middle part of $m$. trapezius to maintain body balance in gravity. Conditions of high physical load (added mass of up to $50 \mathrm{~kg}$ as equipment) could in turn improve the relations.

\section{CONCLUSIONS}

Our study showed that the long-time military mission influenced the skeletal muscles functional state. The decrease in the muscle tone of lower extremities was related to the increase in serum vitamin $25(\mathrm{OH}) \mathrm{D}$ level (in average by $64 \mathrm{nmol} / \mathrm{L}$ ). At the same time the muscle tone of $m$. trapezius increased in our subjects, and this increase was linked to WHR.

\section{REFERENCES}

1. Bizzini M. and Mannion A. F. (2003) Reliability of a new, hand-held device for assessing skeletal muscle stiffness. Clin Biomech (Bristol, Avon) 18, 459-461.

2. Boland R. (1986) Role of vitamin D in skeletal muscle function. Endocrinol Rev., 7(4), 434-448.

3. Ebashi S., Endo M. (1968) Calcium ion and muscle contraction. Prog Biophys Mol Biol., 18, 123-183.

4. Geglia L. (2008) Vitamin D and skeletal muscle tissue and function. Molecular Aspects of Medicine, 29, 407-414.

5. Glerup H., Mikkelsen K., Poulsen L., et al. (2000) Hypovitaminosis D myopathy without biochemical signs of osteomalacic bone involvement. Calcif Tissue Int. 66, 419-429.

6. Gomez-Merino D., Chennaoui M., Burnat P., Drogou C., Guezennec C. Y. (2003) Immune and hormonal changes following intense military training. Mil Med 168, 1034-1038.

7. Hamilton B. (2010) Vitamin D and Human Skeletal Muscle. Scand J Med Sci Sports, 20, 182-190.

8. Heaney R. P., Dowell M. S., Hale C. A., Bendich A. (2003) Calcium absorption varies within the reference range for serum 25-hydroxyvitamin D. J Am Coll Nutr $22,142-6$. 
9. Holick M. F. (2007) Vitamin D Deficiency. N Engl J Med 2007; 357, 266-81.

10. Knussman R. (1988) Anthropolgie. Handbuch der vergleichenden Biologie des Menschen. Band I: Wesen und Methoden der Anthropologie. Stuttgart/New York: Gustav-Fisher Verlag, 139-309.

11. Larson-Meyer D. E., Willis K. S. (2010) Vitamin D and athletes. Curr Sports Med Rep., 9(4), 220-226.

12. Lieber, R. L., Steinman, S., Barash, I. A., Chambers, H. (2004) Structural and functional. changes in spastic skeletal muscle. Muscle and Nerve 29, 615-627.

13. Mheid I. A., Patel R., Murrow J., et al. (2011) Vitamin D Status Is Associated With Arterial Stiffness and Vascular Dysfunction in Healthy Humans. J of the American College of Cardiology 58(2), 186-192.

14. Moran D., Mc Clung J. P., Kohen T., Lieberman H. R. (2013) Vitamin D and Physical Performance. Sports Med., 43, 601-611.

15. Pfeifer M., Begerow B., Minne H. W. (2002) Vitamin D and muscle function. Osteoporos Int. 13(3), 187-194.

16. Report of a WHO Expert Consultation (2008) Waist Circumference and WaistHip Ratio. World Health Organization. 8-11 December 2008, 39 p.

17. Salum E., Zilmer M., Kampus P., Kals J., Unt E., Serg M., Zagura M., Blöndal M., Zilmer K., Eha J. (2011) Effect of a long-term military mission on arterial stiffness, inflammation markers, and vitamin D level. Int J cardiology, doi:10.1016/ j.ijcard.2011.06.017.

18. Sato Y., Iwamoto J., Kanoko T., Satoh K. (2005) Low-dose vitamin D prevents muscular atrophy and reduces falls and hip fractures in women after stroke: a randomized controlled trial. Cerobrovasc. Dis. 20(3), 187-192.

19. Thomson P. D. (1996) The cardiovascular complications of vigorous physical activity. Arch Intern Med 156(20), 2297-2302.

20. Vain A. (1995) Estimation of the functional state of skeletal muscle. In: Veltink $\mathrm{PH}$, Boom HBK,(editors) Control of ambulation using functional neuromuscular stimulation. Enschede:University of Twente, 51-55.

21. Veldre G., Kums T., Salum E., Eha J. (2011) Relationship between soldiers' body height-weight category and changes in their spinal column kyphotic curvature during a long-term military mission. Papers on Anthropology, XX, 423-428.

22. Viir R., Laiho K., Kramarenko J., Mikkelson M. (2006) Repeatability of trapezius muscle tone assessment by a myometric method. J Mech Med Biol 6, 215-228.

\section{Address for correspondence:}

Jaan Eha

Department of Cardiology,

University of Tartu

L. Puusepa 8, 51014 Tartu, Estonia

E-mail: jaan.eha@ut.ee 